\title{
Responsiveness of Capital Market on the Output of Manufacturing Firms in Nigeria
}

\author{
Madubuko Cyril Ubesie \\ $\&$ \\ Matthew Emeziem Ude \\ Department of Accountancy, Faculty of Management Sciences \\ Enugu State University of Science and Technology (Esut), Enugu, Nigeria \\ E-mail: ubesiemadubuko@yahoo.com
}

Received: Jan. 26, 2019 Accepted: Feb. 20, 2019 Published: April 19, 2019

doi:10.5296/ifb.v6i1.14693 URL: http://dx.doi.org/10.5296/ifb.v6i1.14693

\begin{abstract}
Capital market provides the necessary lubricant that keeps turning the wheel of the economy. It does not only provide the funds required for investment but also efficiently allocates these funds to projects of best returns to investors. This study empirically examined the responsiveness of capital market on productivity (Output) of manufacturing firms in Nigeria (1990 - 2016). Specifically, the study examined the impact of Market capitalization, Total listed equities and All Share Index on the productivity (Output) of manufacturing firms in Nigeria. Annual time series data obtained from the Central Bank of Nigeria (CBN) statistical bulletin, 2016 edition was utilized. The study adopted the ex-post facto research design and employed the Autoregressive Distributed Lag (ARDL) bound test approach. The findings revealed that capital market indices of the Nigerian Stock Exchange (proxy by MCAP, TLE, and ASI) have long-run significant influence on the productivity of manufacturing firms in Nigeria. Based on these findings, it was recommended among others that there is need to restore confidence to the market by regulatory authorities through ensuring transparency and fair trading transaction and dealings in the stock exchange which in turn will help to improve economic growth in Nigeria; also that the private sector should be encouraged to invest in capital market to boost productivity (Output) and improve the growth of Nigerian economy.
\end{abstract}

Keywords: Output of manufacturing firms, Market capitalization, Total listed equities, All Share Index 


\section{Introduction}

The role of the capital market in Industrial development and economic growth of the country has continued to generate a lot of debates among researchers, economists and policy makers. Some scholars have maintained that the Nigerian Capital Market had performed below expectation as a supplier of cheap and stable funds for Nigeria's industrial sector. For instance, Ariyo and Adelegan (2005) argued that the liberalization of capital market led to the growth of the Nigerian capital market yet its impact at the macro economy was negligible.

Capital market is an economic institution which promotes efficiency in capital formation and allocation. According to Ndako (2010), the capital market is a complex institution through which long-term funds of the major sectors of the economy comprising households, firms, and government are mobilized, harnessed and made available to various sectors of the economy. Despite the fact that Nigeria's capital market had experienced growth as indicated by growth of its performance indicators, the industrial sector (especially the manufacturing sector) growth has not been impressive (Al-Faki, 2006).

The successive government's effort to promote the industrial development in the country has also remained negligible. Manufacturing sector which has been identified as the engine room of economic growth and the major determinant in achieving macroeconomic goal, has continued to decline progressively over the period. This is attributed partly to lack of long-term funds that is required to galvanize the sector in providing impetus for inclusive growth and job creation. Long-term funding which is the bane of the manufacturing sector could be achieved through an active capital market that mobilizes long term funds for the development of small and medium scale industries in Nigeria (Kwode, 2014).

Consequently, in recent times, inclusive economic growth and job creation have been the focal point of most developing countries. This is necessitated by the fact that these countries are experiencing economic growth without development. Nigeria with annual growth rate of 6.5 percent and a rebased GDP of 8 trillion naira making it the largest economy in Africa has not witnessed significant reduction on the level of poverty, income inequality and unemployment. The importance of the manufacturing subsector in the development of Nigeria's economy has long been identified; not only in the area of employment provision but also in respect of raising income and diversifying the Nigeria economy. It is pertinent to mention that the manufacturing sector of Nigeria has passed through stages of development which include the pre-independence era, when manufacturing was limited to primary processing of raw materials for export; the post-colonial era of the 1960s characterized by more vigorous import-substitution; the decade of the 1970s, which witnessed the advent of oil and the enormous resources it provided; the decade of the 1980s that experienced dwindling oil revenue; and the pre-SAP era till date which led to near collapse of the Nigerian economy.

A review of the manufacturing sector indicated that the sector has been performing below expectation, leading to decline in industry productivity. Between 2000 and 2011, over 800 manufacturing industries in Nigeria either shut down or temporarily halted production while capacity utilization in industries have continued to hover around $30 \%$ to $45 \%$ on the average with $100 \%$ overhead cost (Ayayi, 2012). This study therefore investigates the responsiveness 
of capital market on the productivity (Output) of manufacturing firms in Nigeria using data for the period of $1990-2016$.

\section{Review of Empirical Literature}

Large amount of study exists examining the role of capital market in economic growth of an economy. This study however reviews the recent studies in this regard. Oke and Adeusi (2012) examined the effect of capital market on economic growth in Nigeria, using time series data from 1981 to 2012. The study adopted the ordinary least squares (OLS) regression technique within the framework of co-integration and error correction mechanism. The results of the cointegration analysis showed that there is a long run relationship among the variables. The results of the short run error correction model revealed that capital market promoted economic development in Nigeria during the period.

Ifionu and Omojefe (2013) investigated the impact of capital market on economic growth in Nigeria, using annual time series data spanning the period from 1985 to 2010. The analysis was carried out under the framework of error correction mechanism. The result of the cointegration test indicated that there is long run relationship among the variables. The results of the short run dynamics revealed that capital market has positive impact on economic growth in Nigeria via market capitalization both in the short run and in the long run.

Employing the ordinary least squares (OLS) regression technique, Nwaolisa, Kasie and Egbunike (2013) examined the impact of capital market on economic growth in Nigeria during the democratic dispensation covering the period from 1999 to 2011 . The result of the study found that capital market has positive but insignificant impact on economic growth inNigeria during the evaluation period.

Udegbunam (2002) examined the effect of openness, stock market development and industrial growth in Nigeria, utilizing annual time series data covering the period from 1970 to 1997 . This study employed the granger causality test and ordinary least squares (OLS) regression techniques in testing the causality relationship and in estimating the specified relationship, respectively. The result of the granger causality test showed that there is no causal relationship between stock market development, openness and economic growth in Nigeria during the evaluation period. The empirical results of the OLS estimate however showed that stock market development has positive and significant relationship with economic growth in Nigeria.

In his empirical study, Oke (2012) examined the effect of capital market activities on the development of the Nigerian oil industries, utilizing annual time series data covering the period from 1999 to 2009 under the framework of cointegration technique and error correction mechanism. The result of the cointegration test showed that there is equilibrium long run relationship among the variables in the model. The results of the empirical estimation showed that stock market capitalization and stock market prices have positive effect on the development of oil and gas industry in Nigeria in the short run but negative impact on the sector in the long run.

Victor, Kenechukwu and Richard (2013) undertook analysis into the effect of capital market 
on Nigeria's industrial sector development, using data from 1980 to 2008 using descriptive statistics methods. The authors employed Ordinary least squares (OLS) regression technique and discovered that capital market has positive relationship with industrial sector development in Nigeria.

The study of Chete, Adeoti, Adeyinka, and Ogundele (2016) focused on the lessons and challenges in industrial development and growth in Nigeria. The authors employed descriptive statistics and revealed that the industrial sector accounts for 6 percent of economic activity while the manufacturing sector contributed only 4 percent to GDP in 2011. The result provided evidence that the primary sector, in particular, the oil and gas sector, dominates the gross domestic product accounting for over 95 percent of export earnings and about 85 per cent of government revenue between 2011 and 2012.

Ibi, Joshua, Eja, and Olatunbosun (2015) empirically examined the relationship between capital market and industrial sector development in Nigeria, utilizing annual time series data covering the period from 1980 to 2012 . The study utilized modern econometric techniques such as the unit root test, co-integration test, granger causality test and the error correction mechanism (ECM). The findings revealed that there exists a long run equilibrium relationship among the variables. It also shows that there is a bi-directional relationship between industrial output and market capitalization and between industrial output and number of deals, but a unidirectional causality relationship running from industrial sector development to value of transaction. More so, the results of short run dynamics revealed that capital market has positive and significant impact on industrial output in Nigeria via market capitalization and number of deals while value of transaction has negative and significant impact on industrial output in Nigeria for the period under review.

Akinlo and Lawal (2015) worked on the impact of exchange rate on industrial production in Nigeria from 1986-2010. They used Vector Error Correction Model (VECM), and discovered that there exist a long run relationship between industrial production index, exchange rate, money supply and inflation rate in Nigeria. Specifically, they revealed that exchange rate depreciation had no perceptible impact on industrial production in the short run but had positive impact in the long run.

Onudukwe (2016) examined the impact of capital market on economic growth in Nigeria for the period of 1980-2014. The study employed Granger causality test, Error Correction Model (ECM) and Ordinary Least Squares (OLS) regression techniques. The result revealed a significant positive impact of capital market on economic growth of Nigeria.

Adeoye (2015) analyzed the impact of the Nigerian capital market on the Nigerian economy for the period of twenty years (1992-2011). Using the ordinary least squares (OLS) multiple regression analyses, the researcher discovered that capital market has a non-significant impact on the economy within the period under review.

Atoyebi, Ishola, Kadiri, Adekunjo and Ogundeji (2013) analyzed the impact of capital market on economic growth in Nigeria for the period of 1981 to 2010. The study used Ordinary Least Squares (OLS) Regression and Vector autoregressive techniques. The findings revealed 
a significant positive relationship between the real gross domestic product and market share index as well as market capitalization in Nigeria.

Emeh and Chigbu (2014) examined the impact of capital market on economic growth in Nigeria using a time series data covering 1985 -2012. The study utilizes regression analysis incorporating multivariate co-integration and error correction model and found out that there exists a negative and significant impact of capital market on economic growth.

Ibrahim, Presley and Scholastica (2014) investigated the impact of capital market activities on economic growth in Nigeria using vector autoregressive (VAR) methodology. The investigation revealed that increase in capital market activities contributed significantly to economic growth. Also, the findings show that there is a long-run relationship between economic growth and capital market activities.

Briggs (2015) empirically examined the impact of the capital market on the Nigerian economy from 1981-2011. The study used Gross Domestic Product (GDP) as proxy for economic growth while the capital market variables considered were; Market capitalization (MCAP), Total New issues (TNI), Value of Transactions (VLT), and Total Listed Equities and Government Stocks (LEGS). Johansen co-integration and Granger causality tests were applied. The result showed that there is a long run relationship between capital market and the growth of the Nigerian economy. The result also showed the clear relative positive impact the capital market plays on the economic growth and invariably on the economy.

Following the need to deregulate financial markets, Kimeli (2017) studied IFRS adoption and capital markets. Through a review of relevant literature, the study investigated the various theories related to financial disclosure, and critically analyzed various empirical studies on the IFRS adoption effects on the functioning and operations of capital markets. Regression analysis techniques including the robust tests such as linearity; multicollinearity; normality and heteroscedasticity were not performed casting doubts on the reliability of the models used. The findings of the review indicate tremendous benefits arising from IFRS adoption to capital markets, this include, enhance liquidity of markets, minimized information asymmetry, lower costs of capital, increase of cross listings by firms, improved foreign holdings and higher turnover of capital markets.

\section{Methodology}

The study adopted ex-post facto research design. Data used were annual time series secondary data extracted from the National Bureau of Statistics (NBS) and Central Bank of Nigeria (CBN) Statistical Bulletin (2017), Published Journals, annual reports and textbooks. The variables under investigation were Market Capitalization (MCAP), All Share Index (ASI) and Total Listed Equity (TLE) as independent variable. The dependent variable was the Output of the manufacturing sector. The choice of these variables was based on their direct impact on the lives and well-being of the people locally and internationally.

The fundamental model adopted was the neoclassical growth model, otherwise referred to as the growth accounting framework to explain the source of growth in an economy. The choice of this model is anchored on the fact that it specifies output as a linear function of Labour (L), 
Capital (K) and the index of technology (A), expressed as:

$$
Y=F(K, L, T)
$$

Where:

$\mathrm{Y}$ is output,

$\mathrm{K}$ is physical capital,

$\mathrm{L}$ is labour force and

$\mathrm{A}$ is an index of technology or efficiency parameter.

Relating it to this study, it is expressed that:

$$
O M S=f(M C A P, T L E, A S I)
$$

Where:

OMS = Output of manufacturing firms,

MCAP $=$ Market capitalization,

TLE $=$ Total Listed equities,

ASI $=$ All Share Index

Particularly,the dynamic Autoregressive Distributed Lag (ARDL) model used when series of the variables are not integrated of the same order (Wooldridge,2009) was employed. Conventionally, the ARDL model with p-lags of Y and r-lags of X (i.e., ARDL ( $p, r)$ can be written as:

$$
Y_{t}=\alpha+\beta_{1} Y_{t-1}+\ldots+\beta_{p} Y_{t-p}+\delta_{1} X_{t-1} \ldots+\delta_{r} X_{t-r}+\varepsilon_{t}
$$

Where:

$$
\begin{array}{ll}
\mathrm{Y}_{\mathrm{t}} & =\text { Dependent Variable at time } \mathrm{t}, \\
\mathrm{Y}_{\mathrm{t}-1} & =\text { Dependent Variable at time lag 1, } \\
\mathrm{X}_{\mathrm{t}-1} & =\text { Independent Variables at time lag 1, } \\
\alpha & =\text { Constant term, } \\
\beta & =\text { Regression parameters, } \\
\varepsilon & =\text { Random error term. }
\end{array}
$$

Such that:

$$
\begin{aligned}
\operatorname{LOMS}_{t}= & \alpha_{o}+\alpha_{1} \text { VLMCAPt-1 } \\
& +\sum_{i=1}^{m} \theta_{2}{ }_{L} \text { TLLEE } E_{t-i}+\sum_{i=1}^{m} \delta_{3} L A S I_{t-i}+\varepsilon_{t}
\end{aligned}
$$


Where:

OMS = Output of manufacturing sector, (Dependent variable).

MCAP = Market capitalization, (Independent variable).

TLE $=$ Total listed equities, (Independent variable).

ASI $=$ All Share Index, (Independent variable).

$\alpha_{0}=$ Intercept of the regression model

$\varepsilon_{\mathrm{t}} \quad=$ Error term associated with the model.

$\mathrm{L}=$ Logarithm operator

$\nabla=$ Difference operator

$\alpha_{1}, \alpha_{2}$, and $\alpha_{3}$ are the respective regression parameters

Apriori: $\alpha_{i}{ }^{\prime} s \geq 0$

If the existence of long-run relationship among the variables is borne out, the long-run and short run parameters are estimated using the ARDL approach. Then, the error correction representation which shows the speed of adjustment to long-run equilibrium following the short-run shock is estimated.

A general error correction representation of equation is specified as:

$$
\begin{aligned}
L_{O M S_{t}}= & \alpha_{o}+\sum_{i=1}^{m} \varphi_{1} \Delta L M C A P_{t-i}+\sum_{i=1}^{m} \theta_{2} \Delta L T L E_{t-i}+\sum_{i=1}^{m} \delta_{3} \Delta L A S I_{t-i} \\
& +\lambda_{2} E C M_{t-1}+\varepsilon_{t}
\end{aligned}
$$

Where:

$\lambda_{2}$ is the speed of adjustment; $\varphi_{1}, \theta_{2}$, and $\delta_{3}$ represents the coefficients of MCAP, TLE and ASI respectively; $m$ is the lag length, $\mathrm{ECM}_{\mathrm{t}-1}$ is the error correction term (or residual from the cointegration equation), and $\varepsilon_{\mathrm{t}}$ is the uncorrected white noise residual. 


\section{Macrothink

\section{Data Presentation, Analysis and Interpretation of Results}

Table 1. Annualized time series data of output of manufacturing sector (OMS), Market capitalization (MCAP), Total Listed Equities (TLE), and All Shares Index (ASI) in Billions of Naira

\begin{tabular}{lllll}
\hline YEARS & OMS (N'B) & MCAP (N'B) & TLE (N'B) & ASI \\
\hline $\mathbf{1 9 9 0}$ & 84.27 & 16.3 & 12.1 & 423.66 \\
$\mathbf{1 9 9 1}$ & 110.60 & 23.1 & 18.4 & 671.62 \\
$\mathbf{1 9 9 2}$ & 153.47 & 31.2 & 26.2 & 931.02 \\
$\mathbf{1 9 9 3}$ & 221.23 & 47.5 & 41.8 & 1229.03 \\
$\mathbf{1 9 9 4}$ & 354.66 & 66.3 & 61.0 & 1913.23 \\
$\mathbf{1 9 9 5}$ & 414.13 & 180.4 & 175.1 & 3815.12 \\
$\mathbf{1 9 9 6}$ & 477.95 & 285.8 & 279.8 & 5955.14 \\
$\mathbf{1 9 9 7}$ & 546.71 & 281.9 & 276.3 & 7638.59 \\
$\mathbf{1 9 9 8}$ & 620.20 & 262.6 & 256.8 & 5961.88 \\
$\mathbf{1 9 9 9}$ & 713.82 & 300.0 & 294.5 & 5264.19 \\
$\mathbf{2 0 0 0}$ & 826.03 & 472.3 & 466.1 & 6701.18 \\
$\mathbf{2 0 0 1}$ & 989.11 & 662.5 & 648.4 & 10185.08 \\
$\mathbf{2 0 0 2}$ & 1127.23 & 764.9 & 748.7 & 11631.87 \\
$\mathbf{2 0 0 3}$ & 1304.07 & $1,359.3$ & $1,325.7$ & 15559.90 \\
$\mathbf{2 0 0 4}$ & 1516.05 & $2,112.5$ & $1,926.5$ & 24738.65 \\
$\mathbf{2 0 0 5}$ & 1778.73 & $2,900.1$ & $2,523.5$ & 22876.72 \\
$\mathbf{2 0 0 6}$ & 2082.49 & $5,120.9$ & $4,227.1$ & 27647.51 \\
$\mathbf{2 0 0 7}$ & 2401.19 & $13,181.7$ & $10,180.3$ & 48773.31 \\
$\mathbf{2 0 0 8}$ & 2761.55 & $9,563.0$ & $6,957.5$ & 50424.70 \\
$\mathbf{2 0 0 9}$ & 3170.82 & $7,030.8$ & $4,989.4$ & 23091.55 \\
$\mathbf{2 0 1 0}$ & 3578.64 & $9,918.2$ & $7,913.8$ & 24775.51 \\
$\mathbf{2 0 1 1}$ & 4527.45 & $10,275.3$ & $6,532.6$ & 23393.65 \\
$\mathbf{2 0 1 2}$ & 5588.82 & $14,800.9$ & $8,974.4$ & 23432.62 \\
$\mathbf{2 0 1 3}$ & 7233.32 & $19,077.4$ & $13,226.0$ & 36207.08 \\
$\mathbf{2 0 1 4}$ & 8685.43 & $16,875.1$ & $11,477.7$ & 39409.82 \\
$\mathbf{2 0 1 5}$ & 8973.77 & $17,003.4$ & $9,850.6$ & 30867.20 \\
$\mathbf{2 0 1 6}$ & 8903.24 & $16,185.7$ & $9,246.9$ & 26624.08 \\
\hline $\mathbf{2 0 4}$ & & & \\
& & & & \\
\hline
\end{tabular}

Source: CBN statistical Bulletin, 2016. 
LOMS

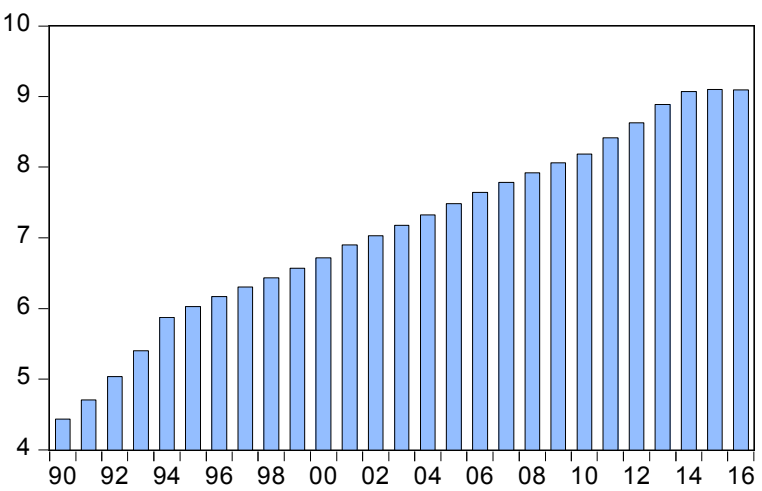

LTLE

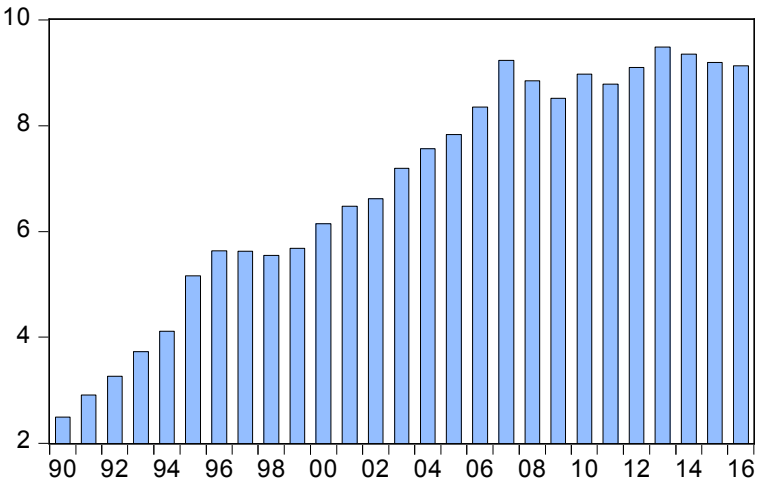

LMCAP

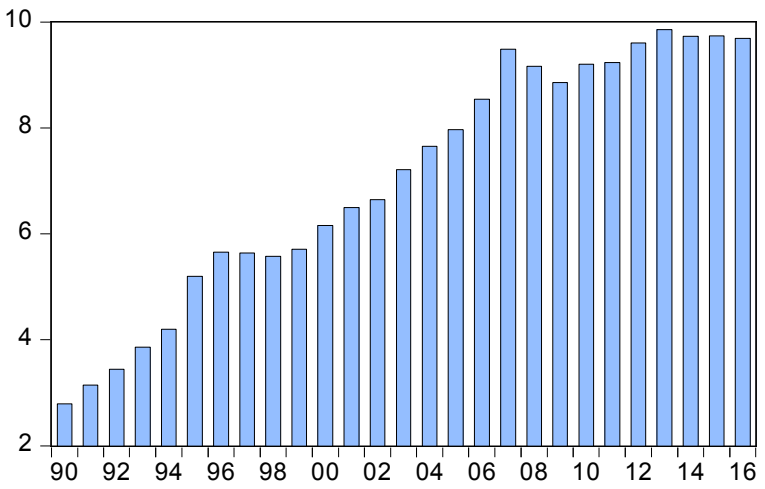

LASI

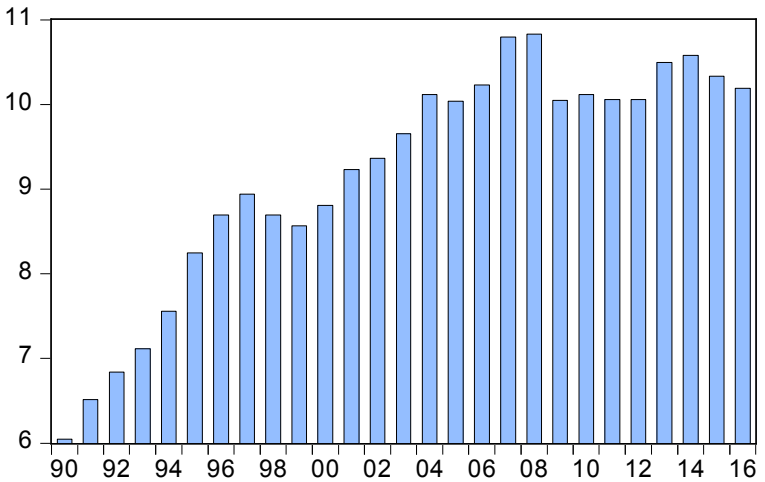

Figure 1. Graphical representation of the variables under investigation

Source: Author's computation, 2018.

The graphical representation indicates that all the variables under investigation exhibit an upward movement over the period. Particularly the graph shows that there was a spike series of MCAP, TLE, and ASI in 2007 respectively and a decline in 2016.

Table 2. Summary of descriptive statistics of the variables under study

\begin{tabular}{ccccccc}
\hline Variables & Mean & Std. Dev. & Skewness & Kurtosis & JB stat. & Prob(JB) \\
\hline OMS & 2560.93 & 2873.66 & 1.26 & 3.26 & 7.23 & 0.0270 \\
MCAP & 5511.08 & 6679.41 & 0.81 & 2.08 & 3.94 & 0.1391 \\
TLE & 3802.12 & 4354.13 & 0.75 & 2.06 & 3.53 & 0.1715 \\
ASI & 17783.11 & 14879.28 & 0.61 & 2.42 & 2.06 & 0.3564 \\
\hline
\end{tabular}

Source: Researcher's extract from EViews 9.0 output (See Appendix I). 


\section{NI Macrothink}

The descriptive statistics result in table 2 shows that output of manufacturing firms (OMS) stood at average value of $\$ 2560.93$ billion with associated standard deviation of $\$ 2873.66$ billion. The mean of market capitalization (MCAP), total listed equities (TLE), and All Share Index (ASI) stood at $\$ 5511.08$ billion, $\$ 3802.12$ billion, and 17783.11 respectively with associated standard deviations of $\$ 6679.41$ billion, $\$ 4354.13$ billion, and 14879.28 respectively. The Jarque-Bera statistics which is a goodness of fit test and a joint test of skewness and kurtosis revealed that with exception of OMS,other variables under investigation follows a normal distribution and without excess kurtosis. The result also shows that all the variables are skewed to the right (i.e., positively skewed).

Table 3. Summary of ADF unit root test

\begin{tabular}{cccccc}
\hline Variable & ADF-Stat & $\mathbf{5 \%} \mathbf{C . V}$ & $\mathbf{p}$-value & $\begin{array}{c}\text { Order of } \\
\text { Integration }\end{array}$ & Inference \\
\hline LOMS & -4.31 & $-3.61^{* *}$ & 0.0121 & $\mathrm{I}(0)$ & Stationary \\
LMCAP & -4.15 & $-3.60^{* *}$ & 0.0163 & $\mathrm{I}(1)$ & Stationary \\
LTLE & -4.57 & $-3.60^{* *}$ & 0.0065 & $\mathrm{I}(1)$ & Stationary \\
LASI & -4.49 & $-3.61^{*}$ & 0.0082 & $\mathrm{I}(1)$ & Stationary \\
\hline
\end{tabular}

** Indicates stationary at $5 \%$ level of significance

Source: Author's extract from EViews 9.0 output (See Appendix II).

The unit root test result above shows that the variables were not integrated of same order. While the dependent variable (LOMS) was stationary at level form (i.e.,I(0)), others (i.e., LMCAP, LTLE, and LASI) were stationary at first differencing. This indicates that the traditional OLS regression technique cannot be used instead the researcher employed the Autoregressive Distributed Lag (ARDL) mechanism.

Table 4. Cointegration test using ARDL bound testing approach

\begin{tabular}{lll}
\hline ARDL Bounds Test & \\
Sample: 19942016 & & \\
Included observations: 23 & & K \\
\hline Test Statistic & Value & 3 \\
F-statistic & 18.34592 & \\
\hline Critical Value Bounds & & I(1)Upper Bound \\
\hline Significance & I(0)Lower Bound & 4.35 \\
$5 \%$ & 3.23 & \\
\hline
\end{tabular}

Source: Researcher's extract from EViews 9.0 output (See Appendix IV). 


\section{Macrothink}

The ARDL bound testwith F-statistic $=18.35>$ lower bound critical valueof 3.23and upper bound critical value of 4.35 at $5 \%$ level indicates that there is a long-run relationship between capital market indices and output of manufacturing firms in Nigeria.

Table 5. Long-run estimates from dynamic OLS (ARDL regression result)

\begin{tabular}{lllll}
\hline Dependent Variable: LOMS & & & \\
\hline Variable & Coefficient & Std. Error & t-Statistic & Prob. $^{*}$ \\
\hline C & 5.627380 & 1.070556 & 5.256501 & 0.0033 \\
LMCAP(-4) & 0.312026 & 0.082475 & 3.783286 & 0.0128 \\
LTLE(-2) & -0.738598 & 0.605581 & -1.219651 & 0.2770 \\
LASI(-4) & -0.206650 & 0.111963 & -1.845703 & 0.1242 \\
\hline F-statistic $=1896.093 ; \quad$ Prob(F-statistic) $=0.000000$ & & \\
R-squared = & & & \\
Durbin-Watson stat $=2.174451$ & & & \\
\hline
\end{tabular}

Source: Researcher's extract from EViews 9.0 output (See Appendix III).

The long-run estimate shows that MCAP is positively and significantly associated with OMS in Nigeria while TLE and ASI are inversely (negatively) and insignificantly related with the OMS for the period under review. Using the Akaike Information Criterion (AIC), the optimal ARDL model selected was ARDL $(4,4,2,4)$. The ARDL estimates above (with F-statistic value of 1896.093; p-value of 0.0000) indicates that capital market indices (market capitalization, listed equities, and All Share Index) at lags 4, 2, and 4 respectively have long-run joint significant influence on the output of manufacturing firms in Nigeria.

The R-square value of 0.999845 is an indication that the model is almost a perfect one as approximately $100 \%$ of the total variations in output of manufacturing firms can be accounted for by changes in capital market in Nigeria. The Durbin-Watson statistic value of 2.174451 confirmed that the model is free from first order autocorrelation problem.

Table 6. ECM representation (Short-run estimates)

\begin{tabular}{lllll}
\hline Dependent Variable: & LOMS & & & \\
\hline Variable & Coefficient & Std. Error & t-Statistic & Prob. \\
\hline C & 6.098207 & 1.448032 & 4.211376 & 0.0006 \\
LMCAP & 1.669555 & 0.674237 & 2.476215 & 0.0241 \\
LTLE & -1.047813 & 0.837123 & -1.251683 & 0.2276 \\
LASI & -0.371848 & 0.273486 & -1.359657 & 0.1917 \\
ECM $(-1)$ & -0.862808 & 3.959114 & -0.217930 & 0.8301 \\
\hline
\end{tabular}

Source: Researcher's extract from EViews 9.0 output (See Appendix V). 
The presence of co-integration or a long-run relationship among the variables demanded specification of the error correction model. The ECM estimates is as presented in table 6 . The coefficient of the error correction term appears with the expected sign (negative sign). This result indicates that capital market indices are sensitive to the departure from its equilibrium value in the previous period.

The coefficient of ECM (-0.862808) which represents the speed of adjustment indicates that the long-run equilibrium is consistent towards convergence once the capital market is disturbed. Particularly, the result shows that about $86.3 \%$ of disequilibrium in the system is corrected every year. This implies that for long-run equilibrium to be restored, it would take the system approximately one year and two months to bring back an equilibrium level again.

\section{Conclusion and Recommendations}

Capital market has remained one of the mainstreams in the development of the economy. This study empirically examined the effect of capital market on the productivity (output) of manufacturing firms in Nigeria from 1990-2016. Using the Autoregressive Distributed Lag (ARDL) bound test technique, the study revealed that capital market measured by market capitalization, total listed equities, and All Share index have mixed effect on the productivity (output) of manufacturing firms in Nigeria. Particularly, the findings revealed that market capitalization interacts positively and significantly with output of manufacturing firms while listed equities and All Share Index has a negative influence on the productivity of the firms. Based on these findings, the following recommendations were made:

1) There is the need to restore confidence to the market by regulatory authorities through ensuring transparency and fair trading transaction and dealings in the stock exchange which in turn will encourage productivity of the manufacturing sector and as well improve economic growth of Nigeria.

2) Given the present political dispensation, all the tiers of government should be encouraged to fund their realistic developmental programme through the capital market as this will serve a long way to freeing the resources that may be used in other aspects of the economy.

3) Policies guiding capital market should be maintained since they foster growth of the manufacturing sector in Nigeria.

4) The illiquidity status of the capital market should be improved to make it more viable for investors to invest, and such overtures can contribute to economic growth. This can be achieved through complete reversal of the ownership structure.

5) The funds raised by government in the form of government securities in the capital market should be put into productive sectors of the economy that will necessitate to growth in all facets of the economy.

\section{References}

Adeoye, A. A. (2015). Impact of the Nigerian capital market on the Nigerian economy. 
European Journal of Accounting Auditing and Finance Research, 3(2), 88-96.

Akinlo, O. O., \& Lawal, Q. A. (2015). Impact of exchange rate on industrial production in Nigeria. International Business and Management, 10(1), 104-110.

Al-Faki, M. (2006). The Nigerian capital market and socioeconomic development. A paper presented at the 4th distinguished faculty of social science, public lectures, University of Benin, 9-16.

Atoyebi, K. O., Ishola, S. A., Kadiri, K. I., Adekunjo, F. O., \& Ogundeji, M. O. (2013). Capital market and economic growth in Nigeria: An empirical analysis. IOSR Journal of Humanities and Social Science (IOSR-JHSS), 6(6), 60-68. https://doi.org/10.9790/0837-0666068

Briggs, A. P. (2015). Capital market and economic growth of Nigeria. Research Journal of Finance and Accounting, 6(9), 82-93.

Chete, L. N., Adeoti, J. O., Adeyinka, F. M., \& Ogundele, O. (2016).Industrial development and growth in Nigeria: Lessons and challenges. Brookings-Learning to Compete; Working Paper, 8, 1-40

Emeh, Y., \& Chigbu, E. E. (2014). The impact of capital market on economic growth: The Nigerian perspective. International Journal of Development and Sustainability, 3(4), 838-864.

Ibi, E. E., Joshua, N. J., Eja, B. R., \& Olatunbosun, H. U. (2015). Capital market and industrial sector development in Nigeria: An empirical investigation. European Journal of Accounting Auditing and Finance Research, 3(6), 63-79.

Ibrahim, B. S., Presley, K. O., \& Scholastica, A. O. (2014). Capital market activities and economic growth in Nigeria: Further evidence from VAR methodology. International Journal of Business and Management Review, 2, 32-47.

Ifionu, E. P., \& Omojefe, G. O. (2013). The capital market and performance of the Nigerian economy: A time series analysis. West African Journal of Industrial and Academic Research, 8(1), 192-207.

Kimeli, E. K. (2017). IFRS adoption and capital markets. Journal of Finance and Accounting, 5(1), 19-30.

Nwaolisa, E. F., Kasie, E. G., \& Egbunike, C. F. (2013). The impact of capital market on the growth of the Nigerian economy under democratic rule. Arabian Journal of Business and Management Review, 3(2), 53-62. https://doi.org/10.12816/0002371

Oke, M. O., \& Adeusi, S. O. (2012). Impact of capital market reforms on economic growth: The Nigerian experience. Australian Journal of Business and Management Research, 2(2), 20-30.

Onudukwe, R. C. (2016). Impact of capital market on economic growth in Nigeria. Retrieved from 
http://www.uniprojectsearch.com/impact-capital-market-economic-growth-nigeria-1980-2014 Udegbunam, R. I. (2002). Openness, stock market development, and industrial growth in Nigeria. The Pakistan Development Review, 41(1), 69-92. https://doi.org/10.30541/v41i1pp.69-92

Victor, O. O., Kenechukwu, N. J., \&Eze, O. R. (2013). Capital market and industrial sector development in Nigeria: A theoretical analysis. Journal of Emerging Trends in Economics and Management Sciences, 4(1), 20-30.

Wooldridge, J. M. (2009). Introductory Econometrics: A Modern Approach (4th ed.). USA: South-Western Cengage Learning Publishers.

\section{Copyrights}

Copyright for this article is retained by the author(s), with first publication rights granted to the journal.

This is an open-access article distributed under the terms and conditions of the Creative Commons Attribution license (http://creativecommons.org/licenses/by/4.0/). 